
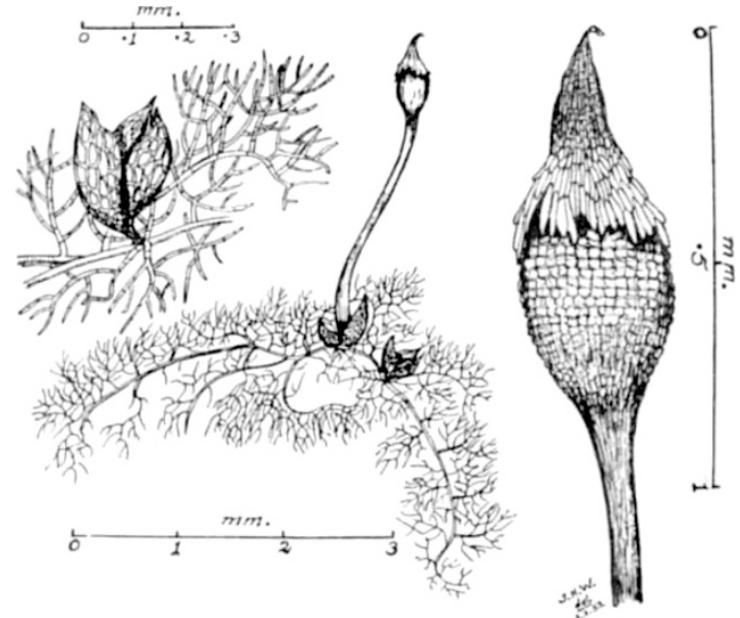

Ephemeropsis trentepohlioides (Renner) Sainsbury, 1951, drawn from a Tasmanian specimen

N.Z.) has kindly examined my Tasmanian collection and pronounces it identical in vegetative characters with the New Zealand $E$. trentepohlioides; he believes that an important extension in the known range of that species has now been established. The discovery of additional Australian material on beech, and probably other rain forest trees or shrubs, is much to be desired.

National Herbarium,

South Yarra, Victoria. Feb. 2.

${ }^{1}$ Renner, O., Ann. Jard. Bot. Buitenzorg, 44, 79 (1934). ' Sainsbury, G. O. K., Trans. Proc. Roy. Soc., N.Z., 79, 203 (1951).

\section{Relation of Witchweed (Striga) to Fertility in Tropical Soils}

MUCH is written upon the subject of soil exhaustion in Africa, and it seems to be generally accepted that the soils of the tropics require careful management, including frequent periods of rest, if fertility is to be maintained. In the great clay plains of the Sudan ${ }^{1}$ in particular, it has been emphatically stated that uncontrolled continuous cultivation of land around water points and villages is responsible for the poor crops and general poverty of the villagers, and that only the provision of new villages at new water points, where cultivation can be rigidly controlled, can solve the problem. It cannot be doubted that soil erosion is responsible for reduction of yields in some cases. The question then arises, what is the reason for the very markedly poor yields of the grain and fodder crop, Sorghum vulgare, Pers., on the village cultivations, where soil erosion is not marked? The answer in the northern and central Sudan seems to be the root parasite Striga hermontheca, Benth., which is prevalent in more or less degree wherever this crop is grown, being indigenous as a parasite of the native grasses. By suitable treatment with hormone weedkillers $^{2}$ it has been shown that it is possible to kill much of the Striga and bring about very considerable increases in yield on irrigated land. During the 1952 season, an experiment was carried out on a piece of village land near Gedaref, in the eastern Sudan, which has been under cultivation for longer than can be remembered by the oldest inhabitants.
The result was that sorghum on the untreated plots yielded $427 \mathrm{lb}$. of heads to the acre, whereas that on plots treated against Striga yielded 1,183 lb. of heads to the acre ( $P$ better than 5 per cent). This latter would be a fairly good yield for newly opened land.

It is interesting to note that one of the criticisms which has been levelled against the practice of this treatment for Striga control is that it will make possible cultivation without rotation on village lands. If, however, as here, the removal of Striga is capable of raising the yield on so-called 'worn-out' lands to a level comparable with yields obtainable from newly opened land, the reply might be made by asking whether the land is worn out, or merely overparasitized? Only further experimentation will show whether, as a recent summary ${ }^{3}$ states, Striga is only serious on worn-out soils, or whether, as I suggest, the 'wearing-out' is due to Striga, on these lands of marginal rainfall.

Sudan Dept. of Agriculture and Forests,

$$
\text { K. WrLson JoNEs }
$$

Research Farm,

Wad Medani.

Feb. 15.

1 Jefferson, J. H. K., Sudan Notes and Records, 30 (1949).

"Andrews and Wilson Jones, Annual Report, Research Division Lepartment of Agriculture and Forests, Sudan Government. 1947-48 (unpublished). Wilson Jones, Empire J. Exp. Agric. (April 1952).

${ }^{3}$ Porteres, R., African Soils, 2, 1 (1952).

\section{An Effect of Parasitism on Balanus balanus (L.) da Costa}

THE parasitism of barnacles of many species by various isopods, gregarines and trematodes, often with the resultant castration of the host, is well known. Recent observations on Balanus balanus collected in the Firth of Clyde, at a depth of about 20 metres, have shown that parasitism may not result in complete castration, but only in nonliberation of the nauplii.

This barnacle spawns during the spring: a collection was made when the main spawning period was known to have ended, and several hundred individuals of all size-groups examined for the state of the ovaries. Only a single individual was found with embryos, the remainder being either immature or spent. Further examination showed this individual to be heavily parasitized by a protozoan, and although not specifically identified it seems probable that it was a gregarine, these being known to be of common occurrence in other Balanus species ${ }^{1}$.

On teasing out into sea water, the liberated stage I nauplii appeared to be quite normal, swimming vigorously. However, within a few minutes almost all the nauplii (stage I) had moulted to give normal stage II nauplii.

It would seem, therefore, that the presence of the parasite, while not effecting castration, had prevented normal release of the nauplii, and that development of the latter had continued to some extent within the mantle cavity, so that on release extremely rapid moulting to stage II took place.

The Marine Station,

H. Barnes

$$
\text { Millport, }
$$

Isle of Cumbrae.

Feb. 23.

${ }^{1}$ Henry, D. P., Arch. Protistenk., 90, 414 (1938). 